\title{
IMMOBILIZATION OF RADIOACTIVE WASTE IN CEMENT: IODINE BINDING BY CEMENTITIOUS MATERIALS UNDER HIGHLY ALKALINE CONDITIONS
}

\author{
R. Druteikienė, J. Šapolaitė, Ž. Ežerinskis, E. Naujalis, and A. Puzas \\ Center for Physical Sciences and Technology, Savanoriu Ave. 231, LT-02300 Vilnius, Lithuania \\ E-mail: ruta@ar.fi.lt
}

Received 8 October 2014; revised 4 December 2014; accepted 20 March 2015

\begin{abstract}
This work is directed to assess iodine interactions with hardened cement paste (HCP) under highly alkaline conditions $(\mathrm{pH}>12)$ with/without a reductant. For this purpose, a series of $K_{\mathrm{d}}$ (distribution coefficient) experiments using ${ }^{127} \mathrm{I}$ as a tracer were performed. The $K_{\mathrm{d}}$ values of iodine were in the order of $172-1095 \mathrm{~mL} \mathrm{~g}^{-1}$ in the batch experiment without a reductant, and in the order of $83-92 \mathrm{~mL} \mathrm{~g}^{-1}$ in the experiment with a reductant. The percentage of iodine leached out from HCP throughout the experiment suggested its very strong binding with cementitious materials. The obtained results allow supposing that chemical speciation of iodine has influence on the interaction of iodine with HCP under highly alkaline conditions.
\end{abstract}

Keywords: iodine, cement, sorption, desorption, $K_{\mathrm{d}}$

PACS: 28.41.Kw, 68.43.Mn, 68.43.-h, 82.80.Bg, 07.75.th

\section{Introduction}

Function of the repository engineered barrier system is to ensure safe disposal of radioactive waste and to prevent uncontrolled migration of radionuclides outside the control area. The migration of radioactive nuclides from the repository through the containers and engineered barriers is induced because of their disintegration by groundwater, microorganisms, cement degradation, and corrosion. Final disposal of long-lived radioactive waste in the repositories implies the long-term risk related to their potential spreading in the surrounding solid and liquid phases.

Solidification of low and intermediate level radioactive waste by cementitious materials is one of the most frequently applied techniques prior to the nearsurface or underground disposal [1-3]. Cement (concrete) is used to construct the engineered barriers of the repository as backfill material in vaults and tunnels. High mechanical capacity, low hydraulic conductivity and high radionuclide retention capacity are characteristic of cement. The most abundant cement mineral in hardened cement paste (HCP) is calcium silicate hydrate $(\mathrm{CSH})$ [1-3], which is capable of im- mobilizing many radionuclides. The interaction of groundwater with hardened cement paste can bring about a chemical alteration therein, and further degradation of concrete [4, 5]. Degradation of hydrated cement involves dissolution and leaching related to processes such as carbonation (dissolution of portlandite) and decalcification (ionic leaching from dissolution of portlandite and calcium-silicate-hydrate) [5]. These processes induce gradual changes in the composition of the pore water, from typical "young" cement leachate with a $\mathrm{pH}$ above 13 to leachate with a $\mathrm{pH}$ lower than 10 [ 6 . It has been shown that calcium silicate hydrates are a determining factor in the immobilization of di-, tri-, and hexavalent radionuclides in cementitious materials [1-3].

Several mechanisms have been postulated for the radionuclide immobilization in cement pore water, including precipitation as a simple salt, co-precipitation with other phases, lattice incorporation, chemisorption/physical adsorption, complex and colloid formation in the aqueous phase [7]. The retention of radionuclides in the cement matrix is determined by the formation of solubility-limiting phases because of chemical reactions of radioactive species with cement components [何. 
Iodine-129 is a fission product present in the spent fuel from nuclear power plants and it is considered as a key mobile radionuclide for the disposal of spent fuel and high-level radioactive waste [8-10]. The behaviour of iodine in the geomedia is of particular importance because of its long half-life $\left({ }^{129} \mathrm{I}, T_{1 / 2}=1.57 \cdot 10^{7}\right.$ years), its radiotoxicity, and its chemistry [11]. Since iodine is very much soluble, it easily migrates along water pathways if it enters the environment [12]. The knowledge of the extent of the iodine interaction with engineered barriers is of vital importance in modelling the iodine release from irradiated nuclear reactor fuel elements stored in underground vaults.

A number of studies on the mechanism of the iodine uptake in cementitious materials have been conducted [12-16]. Most of the studies have focused on the investigations of the potential of individual cement minerals to immobilize iodine and elucidation of a molecular-scale mechanism for the $\mathrm{I}^{-} / \mathrm{IO}_{3}^{-}$interaction with $\mathrm{HCP}$ and $\mathrm{CSH}$. The iodine species uptake by cement and CSH was studied using XAS and EXAFS [14]. The authors concluded that redox reactions did not influence sorption of the iodine species by $\mathrm{HCP}$ and CSH. Moreover, the EXAFS/XANES studies demonstrated that $\mathrm{CSH}$ was not the phase controlling $\mathrm{IO}_{3}^{-}$uptake in HCP.

The objective of this study was to investigate iodine interactions with cementitious materials under ambient highly alkaline conditions $(\mathrm{pH}>12)$ with/without reductant $\mathrm{Na}_{2} \mathrm{~S}_{2} \mathrm{O}_{4}$ because the interaction of iodine under ambient conditions remains poorly characterized. For this purpose, a series of $K_{d}$ and sorption/desorption kinetics experiments, using ${ }^{127} \mathrm{I}$ as a tracer, was performed. The concentrations of iodine in a solution were measured by ICP-MS (inductively coupled plasma mass spectrometer). The distribution coefficient $K_{\mathrm{d}}$ for ${ }^{127} \mathrm{I}$ in a cement-water system was determined.

\section{Experiment}

\subsection{Materials}

Solutions were made from reagent grade chemicals in deionized water prepared by the water purification system TKA LAB MICRO (conductivity $0.055 \mu \mathrm{S} \mathrm{cm}^{-1}$; TOC $<10 \mathrm{ppb}$ ). Polyethylene centrifuge tubes used in the batch sorption experiments were washed, left overnight in a solution of $0.1 \mathrm{~mol} \mathrm{~L}^{-1} \mathrm{HCl}$, and thoroughly rinsed with deionized water prior to use. For the sorption studies, concentration of KI in solution was $3.15 \cdot 10^{-6} \mathrm{~mol} \mathrm{~L}^{-1}$. All experiments were carried out under ambient conditions, but the samples were protected from the sunlight to avoid photochemical reaction of the iodine species.
All batch experiments were performed in triplicate and all experimental data are the averages of triplicate determination. The relative errors of the data were about $10 \%$.

\subsection{Measurements}

Measurements of ${ }^{127} \mathrm{I}$ and major cation concentrations were carried out with an inductively coupled plasma sector field mass spectrometer (ELEMENT2, Thermo Scientific, Germany). All parameters regarding the ICP-SFMS (inductively coupled plasma sector field mass spectrometer) are shown in Table 1 below.

Table 1. General parameters of the ICP-SFMS.

\begin{tabular}{cc}
\hline ICP-SFMS & \\
\hline Plasma power & $1350 \mathrm{~W}$ \\
\hline Cool gas & $14.00 \mathrm{~L} \mathrm{~min}^{-1}$ \\
\hline Auxiliary gas & $0.7 \mathrm{~L} \mathrm{~min}^{-1}$ \\
\hline Sample gas & $1.2 \mathrm{~L} \mathrm{~min}^{-1}$ \\
\hline Sample time & $0.05 \mathrm{sec}$ \\
\hline Spray chamber & Cyclonic \\
\hline Nebulizer & $\mathrm{X}$ type, $400 \mu \mathrm{L} \mathrm{min}^{-1}$ \\
\hline Scan type & EScan \\
\hline Sample and skimmer cones & Nickel \\
\hline
\end{tabular}

Measurements of the iodine speciation were carried out with the high pressure liquid chromatography (HPLC) system (Agilent 1100, Germany) coupled to an inductively coupled plasma sector field mass spectrometer ELEMENT2 equipped with a cyclonic spray chamber (Glass Expansion, Australia). All parameters regarding the ICP-SFMS and the sample introduction system are shown in Table 1 .

The ion HPLC system was equipped with a ZORBAX SAX anion exchange column $(4.6 \times 150 \mathrm{~mm}$ 5-Micron, Agilent Technologies, USA) and in addition we used a ZORBAX SAX guard column $(4.6 \times 12.5 \mathrm{~mm})$. Samples were injected with a $1 \mathrm{~mL}$ injection loop. Pre-cleaned $10 \mathrm{~mL}$ plastic syringes were used to fill the sample loop. Phthalic acid $0.01 \mathrm{~mol} \mathrm{~L}^{-1} 6.5 \mathrm{pH}$ solution was used as an eluent for this system. In the first step iodine was pre-concentrated on the column using only UPW (ultra pure water) ( $0-5 \mathrm{~min}$ ) followed by the elution with $0.01 \mathrm{~mol} \mathrm{~L}^{-1} \mathrm{C}_{6} \mathrm{H}_{4}\left(\mathrm{CO}_{2} \mathrm{H}\right)_{2}(5-10 \mathrm{~min})$. The flow speed was $1 \mathrm{~mL} \mathrm{~min}^{-1}$. Chromatographic data analysis software (Xcalibur, Thermo Scientific, Bremen, Germany) was used for the peak integration.

The redox potential (Eh) and $\mathrm{pH}$ of solutions were measured using the WTW $\mathrm{pH}$-meter $\mathrm{pH} 315 \mathrm{i}$ with a combined glass/reference electrode calibrated against standard buffers $\mathrm{pH} 4$ and $\mathrm{pH} 7$ (HANNA pH standard buffer solutions, Sigma-Aldrich Chemie) with a measurement error of \pm 0.01 . 


\subsection{SEM and XRD characterization}

Commercial Portland cement (CEM II/A-LL 42.5 W, Akmenes Cementas, Lithuania) was used for iodine sorption/desorption experiments. The specific surface area of the cement was $410 \mathrm{~m}^{3} \mathrm{~kg}^{-1}[13]$. The particle sizes of cement were determined with the SEM Helios NanoLab 650 (FEI, Netherlands). Based on the SEM analysis, particle sizes of cement were in the range of 3.06-87.90 $\mu \mathrm{m}$.

XRD analysis of Portland cement was performed by means of the X-ray diffractometer D8 Advance (Bruker AXS, Germany).

The peaks (Fig. 1) marked by [ $\boldsymbol{\nabla}]$ correspond to the calcium silicate oxide in a cement sample. The peaks marked by $[\mathbf{x}]$ and $[\bullet]$ belong to the brownmillerite and calcium aluminum oxide, respectively.

Chemical composition of cement (Table 2) was determined with a fluorescent X-ray spectrometer with wave dispersion (WD-XRF) AxiosmAX (PANalytical, Netherlands) supplied with the software Omnian (PANalytical) for standard-less quantitative analysis.

The main components of cement obtained by $\mathrm{X}$-ray fluorescence were $\mathrm{CaO}(68.57 \%), \mathrm{SiO}_{2}(14.60 \%), \mathrm{Fe}_{2} \mathrm{O}_{3}$ (4.54\%), $\mathrm{Al}_{2} \mathrm{O}_{3}$ (3.28\%), $\mathrm{MgO}$ (2.33\%), $\mathrm{K}_{2} \mathrm{O}(1.17 \%)$. $\mathrm{The} \mathrm{Ca} / \mathrm{Si}$ ratio in cement was found to be 0.14 .

\subsection{Preparation of $\mathrm{HCP}$}

$\mathrm{HCP}$ with the water/cement ratio $\mathrm{W} / \mathrm{C}=1: 3$ was prepared in accordance with Tits et al. [18]. The samples of $\mathrm{HCP}$ were prepared in polyethylene centrifuge tubes
Table 2. Chemical composition of Portland cement (CEM II/A - LL $42.5 \mathrm{~W}$ ).

\begin{tabular}{c|c|c|c}
\hline Element & $\begin{array}{c}\text { Concentra- } \\
\text { tion, \% }\end{array}$ & $\begin{array}{c}\text { Compound } \\
\text { formula }\end{array}$ & $\begin{array}{c}\text { Concentra- } \\
\text { tion, \% }\end{array}$ \\
\hline $\mathrm{O}$ & 35.0 & $\mathrm{O}$ & 1.4 \\
\hline $\mathrm{Na}$ & 0.1 & $\mathrm{Na}_{2} \mathrm{O}$ & 0.2 \\
\hline $\mathrm{Mg}$ & 1.4 & $\mathrm{MgO}$ & 2.3 \\
\hline $\mathrm{Al}$ & 1.7 & $\mathrm{Al}_{2} \mathrm{O}_{3}$ & 3.3 \\
\hline $\mathrm{Si}$ & 6.9 & $\mathrm{SiO}_{2}$ & 14.6 \\
\hline $\mathrm{P}$ & 0.03 & $\mathrm{P}_{2} \mathrm{O}_{5}$ & 0.08 \\
\hline $\mathrm{S}$ & 1.2 & $\mathrm{SO}_{3}$ & 3.1 \\
\hline $\mathrm{K}$ & 1.0 & $\mathrm{~K}_{2} \mathrm{O}$ & 1.2 \\
\hline $\mathrm{Ca}$ & 49.0 & $\mathrm{CaO}$ & 68.6 \\
\hline $\mathrm{Ti}$ & 0.2 & $\mathrm{TiO}_{2}$ & 0.3 \\
\hline $\mathrm{Cr}$ & 0.01 & $\mathrm{Cr}_{2} \mathrm{O}_{3}$ & 0.02 \\
\hline $\mathrm{Mn}$ & 0.05 & $\mathrm{MnO}$ & 0.07 \\
\hline $\mathrm{Fe}$ & 3.2 & $\mathrm{Fe} \mathrm{O}_{3}$ & 4.5 \\
\hline $\mathrm{Ni}$ & 0.01 & $\mathrm{NiO}$ & 0.02 \\
\hline $\mathrm{Cu}$ & 0.03 & $\mathrm{CuO}$ & 0.03 \\
\hline $\mathrm{Zn}$ & 0.02 & $\mathrm{ZnO}$ & 0.03 \\
\hline $\mathrm{Sr}$ & 0.1 & $\mathrm{SrO}$ & 0.1 \\
\hline
\end{tabular}

under Ar conditions. Cement was mixed with deionized water (TKA LAB MICRO system, conductivity $0.055 \mu \mathrm{S} \mathrm{cm}^{-1}$; TOC $<10 \mathrm{ppb}$ ) and left to hydrate at room temperature (relative humidity $70 \%$ ) approximately for 4 months. A powder material was prepared by crushing the bulk material in a mortar under ambient conditions and then it was air-dried. Figure 2 shows the XRD pattern of hydrated Portland cement. The

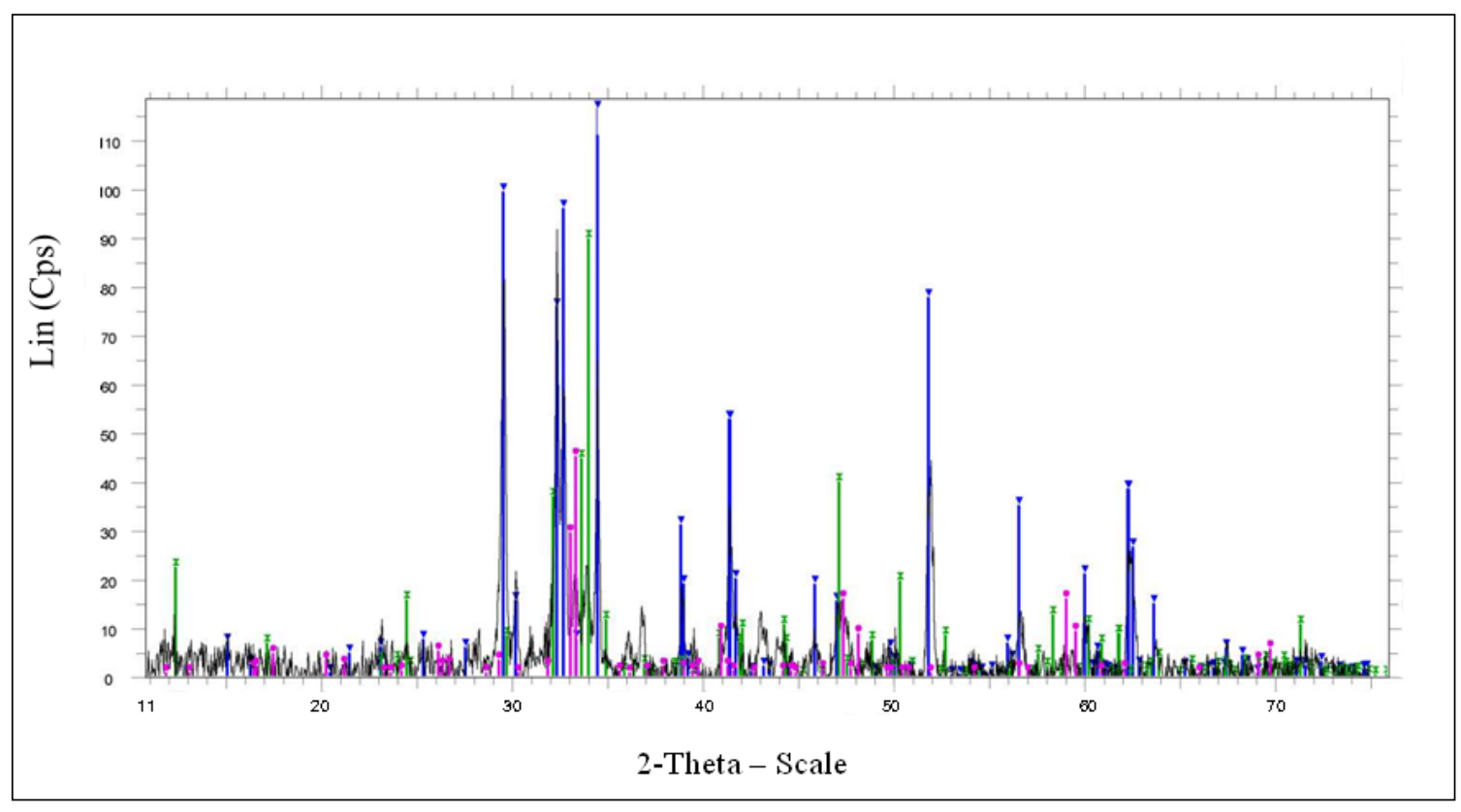

Fig. 1. XRD pattern of Portland cement ([ $\boldsymbol{\nabla}]$ calcium silicate oxide $-\mathrm{Ca}_{3}\left(\mathrm{SiO}_{4}\right) \mathrm{O}-$ Rhombo.H.axes; $[\mathbf{x}]$ brownmillerite $-\mathrm{FeAlO}_{3}(\mathrm{CaO})_{2}$ - orthorhombic; [•] calcium aluminum oxide $-\mathrm{Ca}_{3} \mathrm{Al}_{2} \mathrm{O}_{6}$ - orthorhombic). 


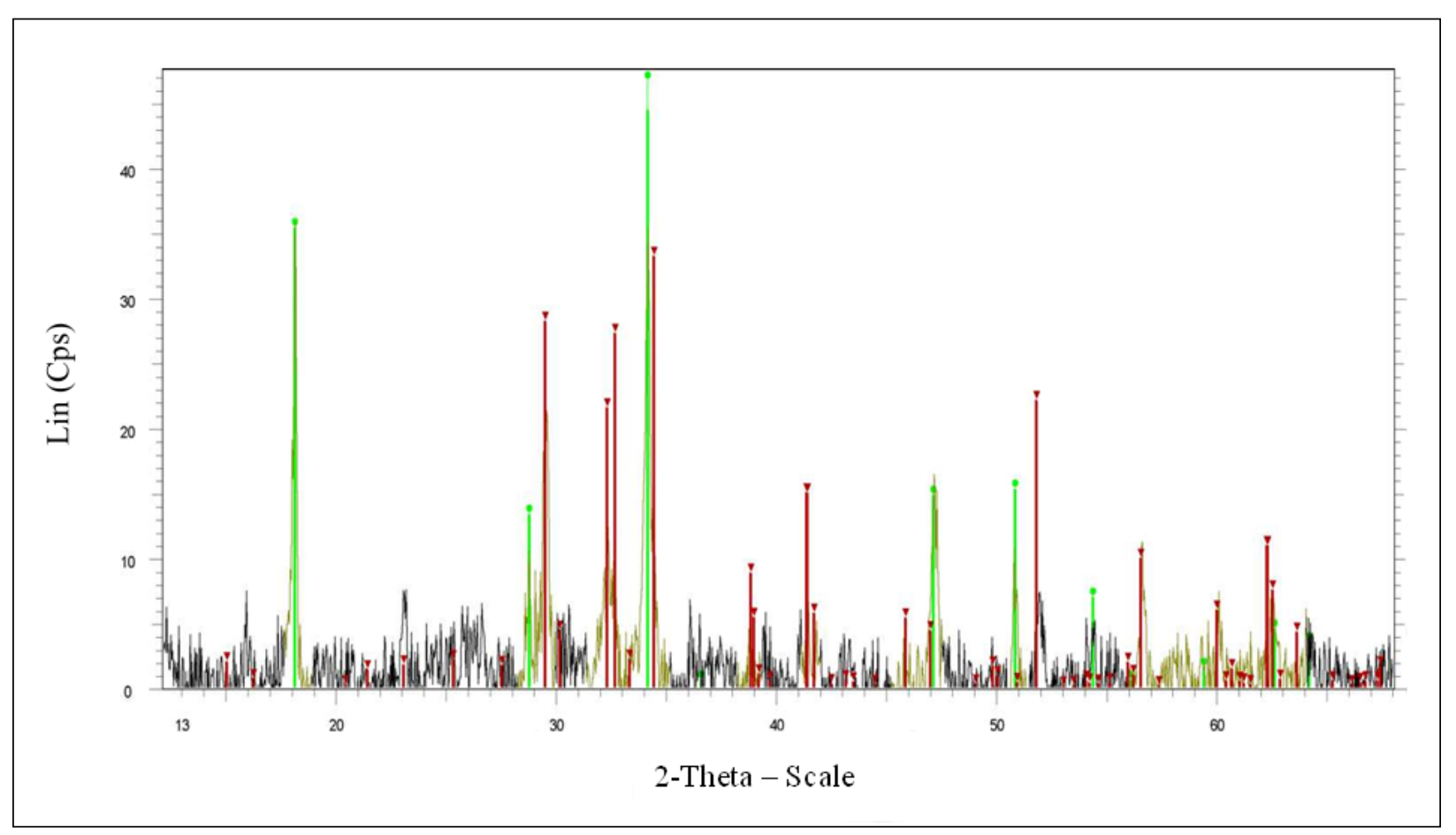

Fig. 2. XRD pattern of hydrated Portland cement $\left([\bullet]\right.$ portlandite, syn $-\mathrm{Ca}(\mathrm{OH})_{2}-34.15 \%$, $[\mathbf{\nabla}]$ calcium silicate oxide $\left.-\mathrm{Ca}_{3}\left(\mathrm{SiO}_{4}\right) \mathrm{O}-23.05 \%\right)$.

peaks marked by $[\bullet]$ are the characteristics of portlandite $\left(\mathrm{Ca}(\mathrm{OH})_{2}, 34.15 \%\right)$ and the peaks marked by $[\mathbf{\nabla}]$ correspond to calcium silicate oxide $\left(\mathrm{Ca}_{3}\left(\mathrm{SiO}_{4}\right) \mathrm{O}\right.$, $23.05 \%)$ in a cement sample.

\subsection{Preparation of cement pore water}

In order to retard the degradation of cement during the batch experiment cement pore water $(\mathrm{CPW})$ was prepared using a method reported by Tits et al. [1]. One gram of hydrated cement powder was added to $25 \mathrm{~mL}$ of deionized water to obtain a solid to liquid $(\mathrm{S} / \mathrm{L})$ ratio of $0.04 \mathrm{~g} \mathrm{~mL}^{-1}$. The suspensions were mixed for 2 weeks on an end-over-end shaker. Liquid phase separation was achieved by centrifuging the samples for 1 hour at $5000 \mathrm{rpm}$ on an Eppendorf (Germany) centrifuge.

The main elements in the solution equilibrated with cement were: $\mathrm{Ca} 93.40 \%$, Fe $2.31 \%$, Sr 2.17\%, Na $1.35 \%$, Ba $0.44 \%$, Ti $0.30 \%$, Si $0.02 \%$.

\subsection{Procedures}

Batch experiments were conducted to determine the distribution coefficient $K_{\mathrm{d}}$ for iodine in cement under alkaline conditions. All the experiments were carried out under ambient conditions. Both $K_{\mathrm{d}}$ and sorption kinetics studies were performed in two series of experiments, with/without a reducing agent $5 \cdot 10^{-3} \mathrm{~mol} \mathrm{~L}^{-1}$ $\mathrm{Na}_{2} \mathrm{~S}_{2} \mathrm{O}_{4}$. All experiments were done in plastic $50 \mathrm{~mL}$ vials to prevent iodine sorption by walls. Deionized water and CPW were used as working solutions. Sorption of iodine on hydrated HCP was investigated using three slightly different approaches. In the first one ( $K_{d}$ experiment, batch I), $25 \mathrm{~mL}$ of deionized water was added to $1 \mathrm{~g}$ of powdered HCP, and the suspensions were shaken for 2 weeks in an endover-end shaker. Then, iodine $\left(\mathrm{I}^{-}\right)$was added from a stock solution (KI, Merck) to reach the concentration of $3.15 \cdot 10^{-6} \mathrm{~mol} \mathrm{~L}^{-1}$. The suspensions were thoroughly stirred, and the $\mathrm{pH} / \mathrm{Eh}$ value was monitored, the vials were corked up, and allowed to shake for 7 days. After equilibration, an aqueous phase was separated and the concentration of iodine was measured with ICP-SFMS.

In the second series of experiments (batch II), $1 \mathrm{~g}$ of powdered HCP was mixed with $25 \mathrm{~mL}$ of CPW, $3.15 \cdot 10^{-6} \mathrm{~mol} \mathrm{~L}^{-1}$ of iodide was added and the suspensions were shaken for 7 days. The third series of experiments (batch III) were performed in parallel with the batch II experiment but using deionized water. The set of duplicate experiments was performed with reductant $\mathrm{Na}_{2} \mathrm{~S}_{2} \mathrm{O}_{4}\left(5 \cdot 10^{-3} \mathrm{~mol} \mathrm{~L}^{-1}\right)$.

All sorption kinetic experiments were carried out according to the same scheme as mentioned above within $1,2,6,14,42$ days.

For desorption experiments, the suspensions of cement were centrifuged $(5000 \mathrm{rpm}, 30 \mathrm{~min})$ at the end of the sorption experiments. The residual cement 
was poured with deionized water. Then the suspensions were stirred in an end-over-end shaker and centrifugation was done under the same conditions as in the sorption experiment.

\subsection{Calculations}

The amount of iodine sorbed on cement and the distribution coefficient $K_{\mathrm{d}}$ were calculated from the following equations [15]:

$$
\begin{aligned}
& \text { Sorption } \%=\frac{C_{0}-C_{\mathrm{eq}}}{C_{0}} \times 100 \%, \\
& K_{\mathrm{d}}=\frac{C_{0}-C_{\mathrm{eq}}}{C_{\mathrm{eq}}} \times \frac{V}{m},
\end{aligned}
$$

where $C_{0}$ is the initial concentration of iodine, $C_{\text {eq }}$ is the final concentration of iodine in a supernatant after centrifugation, $m$ is the mass of cement, $V$ is the volume of aqueous phase.

\section{Results and discussion}

The $\mathrm{pH} /$ Eh was measured regularly at the beginning of the experiment, and then at the end of the experiment. The $\mathrm{pH}$ ranged between 12.2 and 12.5 throughout the experiment in all batch systems; the initial Eh of the suspensions was $-313 \mathrm{mV}$, during the first 24 hours it decreased to $-328 \mathrm{mV}$ and remained relatively stable during the course of the experiment. Constant $\mathrm{pH}$ value of $>12$ indicates $\mathrm{pH}$ buffering by portlandite $\left(\mathrm{Ca}(\mathrm{OH})_{2}\right)$ 20, 21, which was formed in cement (34.5\%; Fig. 2) after 4 months of hydration. The $\mathrm{pH}$ evolution during cement degradation was shown by Jacques et al. [6], who found that $\mathrm{pH}$ higher than 12.5 of the pore water of cement was related to high concentrations of $\mathrm{Na}^{+}$ and $\mathrm{K}^{+}$ions. The dissolution of portlandite reduces $\mathrm{pH}$ of cement pore water to 12 , eventually the $\mathrm{pH}$ of 10 or lower than 10 is controlled by different cement phases (e. g. C-S-H, calcite).

HPLC analysis of iodine shows that the iodine speciation remained unchanged in the solution during the experiment. Figure 3 presents the iodine speciation within the batch I experiment. From Fig. 3 one can see that after 42 days in the $\mathrm{pH}$ range from 12.2 to 12.5 iodide was iodine species. This result is consistent with similar results observed by other authors, e. g. Kaplan et al. [22]. However, under highly elevated oxidizing and basic conditions, iodate may also exist [14], but our experiments showed that ambient experimental conditions inhibited the alteration of iodine speciation.

The effect of addition sequences on iodine sorption on HCP was studied. The addition sequence is different in equilibrating HCP with deionized water for an appropriate period of time and then adding iodide (batch I experiment); spiking iodide to CPW/deionized water and then adding powdered HCP (batch II and III experiments). The results indicated that the sorption of iodine on HCP under experimental conditions was not influenced by the addition sequence. The graphic image of sorption kinetics of iodine on HPC is shown in Fig. 4 .

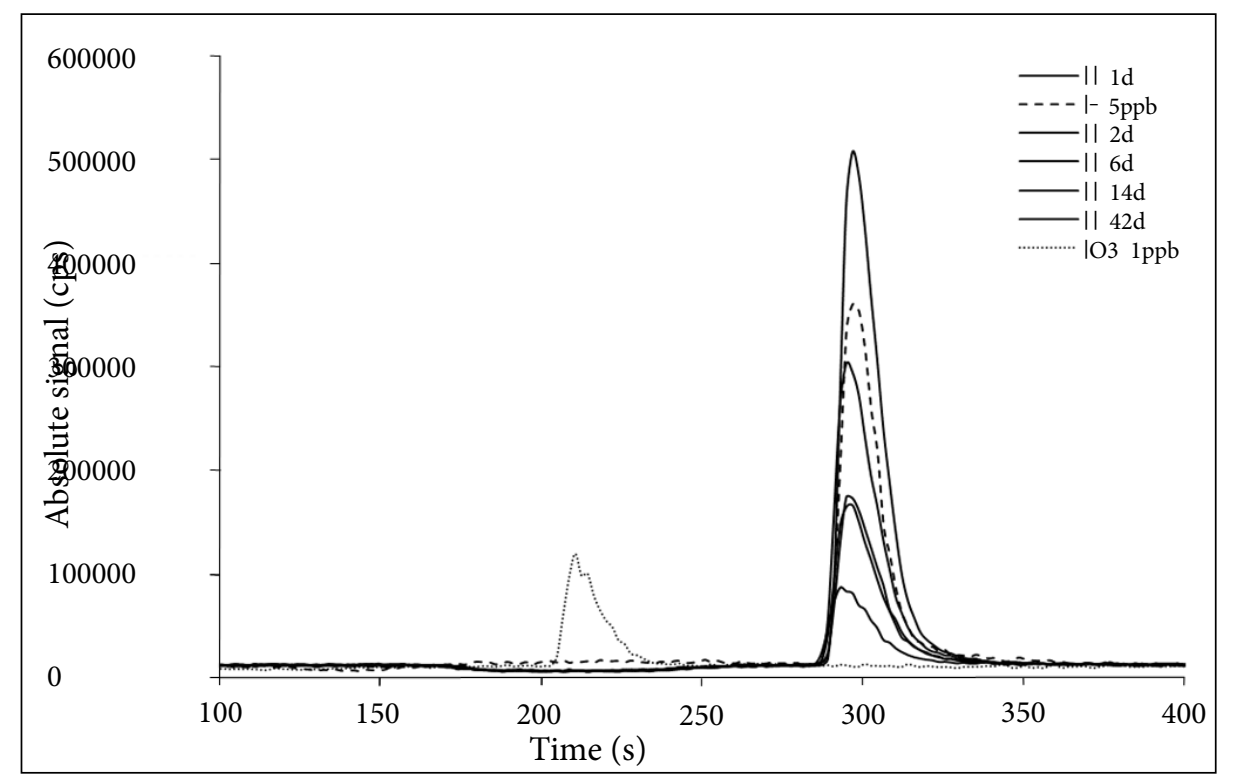

Fig. 3. Iodine aqueous species in solution equilibrated with hydrated HCP (batch I, $\mathrm{pH} 12.18-12.50 ;-313 \mathrm{mV}<\mathrm{Eh}<-328 \mathrm{mV}$ ) within 42 days of the batch experiment (the height of the iodide peaks corresponds to the labels order in the legend). 


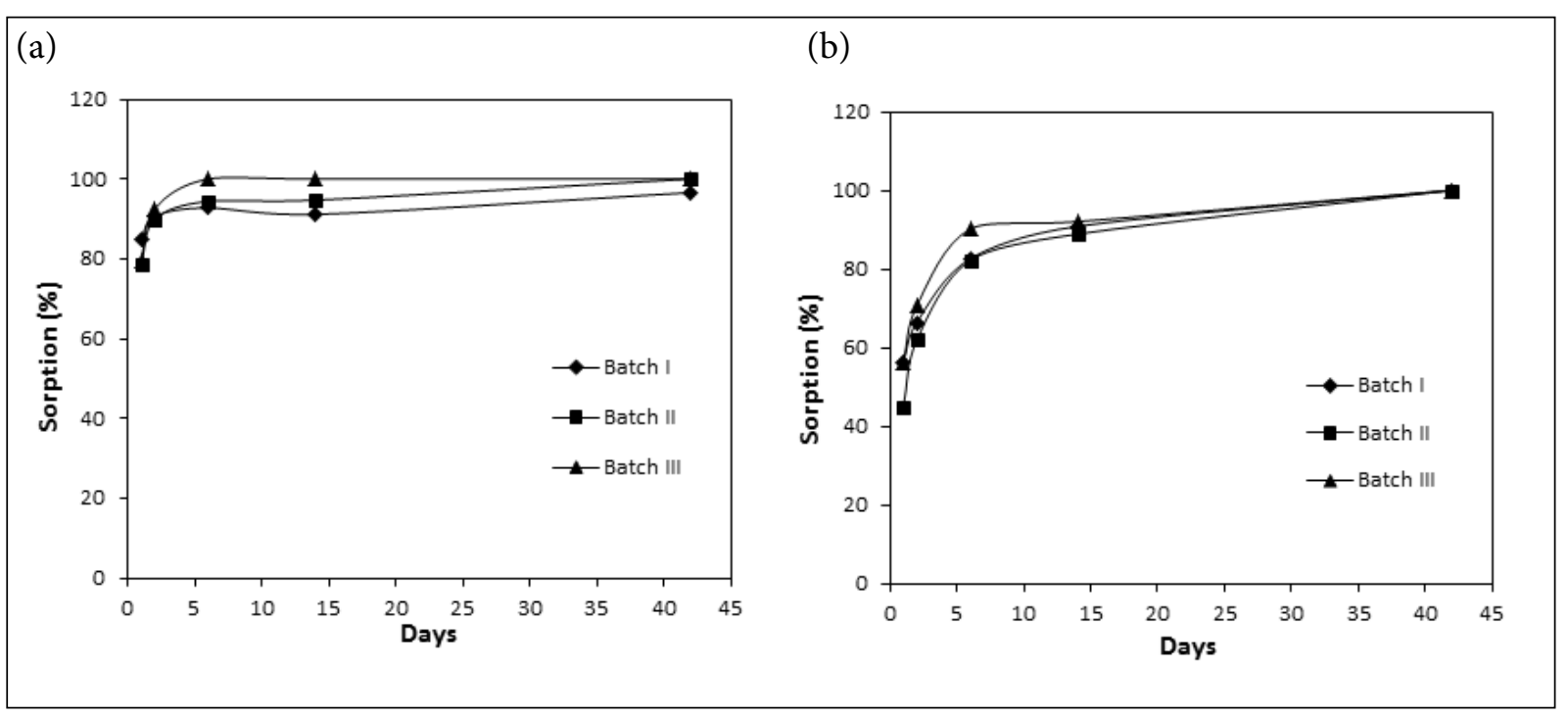

Fig. 4. Kinetics of iodine ( $\left.\mathrm{I}^{-}\right)$sorption on HCP: (a) $\mathrm{pH} 12.18-12.50, \mathrm{c}\left(\mathrm{I}^{-}\right)=3.15 \cdot 10^{-6} \mathrm{~mol} \mathrm{~L}^{-1}, \mathrm{~m} / \mathrm{V}=0.04 \mathrm{~g} \mathrm{~mL}^{-1}$; (b) $\mathrm{pH} 12.18-12.50, \mathrm{c}\left(\mathrm{I}^{-}\right)=3.15 \cdot 10^{-6} \mathrm{~mol} \mathrm{~L}^{-1}, \mathrm{~m} / \mathrm{V}=0.04 \mathrm{~g} \mathrm{~mL}^{-1}, 5 \cdot 10^{-3} \mathrm{~mol} \mathrm{~L}^{-1} \mathrm{Na}_{2} \mathrm{~S}_{2} \mathrm{O}_{4}$.

The sorption of iodine on hydrated cement was mainly attained within one day ( 24 hours) in the batch experiments without reductant, while the steady value of sorption was achieved during 42 days (Fig. $4(\mathrm{a})$ ). The results of the sorption of iodine in the presence of reductant indicate that the uptake process was not so fast, but equilibrium was achieved within 42 days as well (Fig. 4(b)). More detailed results of the sorption, based upon the calculations (Eq. 1), are given in Table 3 .

By comparing the results of both types of sorption experiments (with/without reductant, Table 3), the sorption of iodine on HCP under the investigation conditions ( $\mathrm{pH} 12.2-12.5)$ was slightly different. The results showed that after one day $45-56 \%$ of iodine, when in a reduced form as iodide $\left(\mathrm{I}^{-}\right)$, was immobilized in cement. Hereinafter the amount of iodide in an aqueous phase decreased exponentially till it was completely removed from the solution within 42 days. The results obtained in the batch experiments without a reductant show that the bulk amount of iodine was also removed from the solution after one day of its interaction with HCP but sorption of iodine was slightly higher (79-85\%). Because the HPLC analysis of iodine shows that the iodine speciation remained unchanged in the solution during the experiment, the result of sorption experiments lets one to consider that an alteration of the iodine speciation may occur on the boundary layer of cement and this alteration influenced the iodine behaviour in HCP.

The experiments were conducted in order to obtain the $K_{\mathrm{d}}$ values of iodine species in the cement system under the given experimental conditions (equilibration time $=7$ days). The $K_{\mathrm{d}}$ values (Eq. 2) of iodine were obviously higher in the batch experiment without a reductant, and they ranged from $172 \mathrm{~mL} \mathrm{~g}^{-1}$ in the batch II experiment to $203 \mathrm{~mL} \mathrm{~g}^{-1}$ and $1095 \mathrm{~mL} \mathrm{~g}^{-1}$ in the batch I and batch III experiments, respectively. The $K_{\mathrm{d}}$ values of iodine in the experiment with a reductant were 83,85 and $92 \mathrm{~mL} \mathrm{~g}^{-1}$ in the batch I, batch II and batch III experiments, respectively. The obtained results allow supposing that chemical speciation of iodine has influence on the interaction of iodine with cementitious materials under hyperalkaline conditions.

Table 3. Percentage of iodine sorption on hardened cement paste (HCP) in the batch systems with/without reductant $5 \cdot 10^{-3} \mathrm{~mol} \mathrm{~L}^{-1} \mathrm{Na}_{2} \mathrm{~S}_{2} \mathrm{O}_{4}$.

\begin{tabular}{c|c|c|c|c|c|c}
\hline \multirow{2}{*}{$\begin{array}{c}\text { Sorption } \\
\text { time, days }\end{array}$} & \multicolumn{2}{|c|}{ Sorption, \% (I-, without reductant) } & \multicolumn{3}{|c}{ Sorption, \% $\left(\mathrm{I}^{-}+5 \cdot 10^{-3} \mathrm{M} \mathrm{Na}_{2} \mathrm{~S}_{2} \mathrm{O}_{4}\right)$} \\
\cline { 2 - 7 } & Batch I & Batch II & Batch III & Batch I & Batch II & Batch III \\
\hline 1 & $85 \pm 9$ & $79 \pm 9$ & $80 \pm 9$ & $56 \pm 7$ & $45 \pm 7$ & $56 \pm 7$ \\
\hline 2 & $91 \pm 10$ & $90 \pm 9$ & $93 \pm 10$ & $66 \pm 8$ & $62 \pm 8$ & $71 \pm 8$ \\
\hline 6 & $93 \pm 10$ & $94 \pm 10$ & $<\mathrm{MDL}^{*}$ & $83 \pm 9$ & $82 \pm 9$ & $90 \pm 10$ \\
\hline 14 & $91 \pm 10$ & $95 \pm 10$ & $<$ MDL & $91 \pm 10$ & $89 \pm 9$ & $92 \pm 10$ \\
\hline 42 & $97 \pm 10$ & $<$ MDL & $<$ MDL & $<$ MDL & $<$ MDL & $<$ MDL \\
\hline
\end{tabular}

* Method Detection Limit. 
The reversibility of the iodine uptake by HCP was tested in the desorption experiment. Desorption was started within the first 6 days and a steady state in the iodine desorption was attained within 42 days (Fig. 5).

The percentage of iodine leached out from HCP throughout the experiment suggested its very strong binding with cementitious materials. The amount of iodine obtained in solutions after leaching did not exceed 1-3\% within 42 days. Moreover, the results indicate that the amount of desorbed iodide (batch experiment with $\mathrm{Na}_{2} \mathrm{~S}_{2} \mathrm{O}_{4}$ ) was approximately two times higher than that of iodine in the batch experiment without a reducing agent.

Evans et al. 伵 in the review summarizes the literature data of the binding mechanisms of different radionuclides to cement and states that sorption and/ or lattice incorporation is the main mechanism of the iodine uptake in cement. According to Ojovan et al. 23. physical adsorption is a significant factor for immobilization of radionuclides by cement. Sorption mechanisms depend on the chemical speciation of the radionuclide, and the chemical and physical forms of solid phase [7].

Our sorption/desorption batch-type experiments have shown that iodine immobilization in hydrated
HCP strongly depends on the chemical speciation of iodine. $K_{\mathrm{d}}$ values obtained in the experiment without a reductant are from 2 to 11 times higher than those in the batch experiment with a reductant. In addition, desorption experiments showed that iodide was easily leached out from cement ( 2-3\%) in comparison with iodine $(\sim 1 \%)$ leached out from cement in the batch experiment without a reductant. These results confirmed the lesser affinity of cement phases for $\mathrm{I}^{-}$versus other speciation of iodine [12-14, 19]. For example, the published data indicate that cement has much stronger affinity for iodate than iodide because of a more complex structure of the iodate anion with the surrounding oxygen acting as bridges with the complex cement substrate 证. As Atkins et al. [24] propose, greater affinity of cement phases for $\mathrm{IO}_{3}^{-}$over $\mathrm{I}^{-}$is because of direct bonding between $\mathrm{CSH}$ and $\mathrm{IO}_{3}^{-}$or for the precipitation of $\mathrm{Ca} /$ $\mathrm{IO}_{3}{ }^{-}$containing solid phases. However, the investigation of iodine species $\left(\mathrm{IO}_{3}^{-} / \mathrm{I}^{-}\right)$uptake by $\mathrm{HCP}$ and a $\mathrm{CSH}$ phase under highly alkaline conditions, studied by $K$ edge X-ray absorption spectroscopy, showed that CSH was not the phase controlling $\mathrm{IO}_{3}^{-}$uptake in $\mathrm{HCP}$ [14].

The investigations of iodine speciation in solution equilibrated with HCP showed that no changes of iodine oxidation state occurred within 42 days
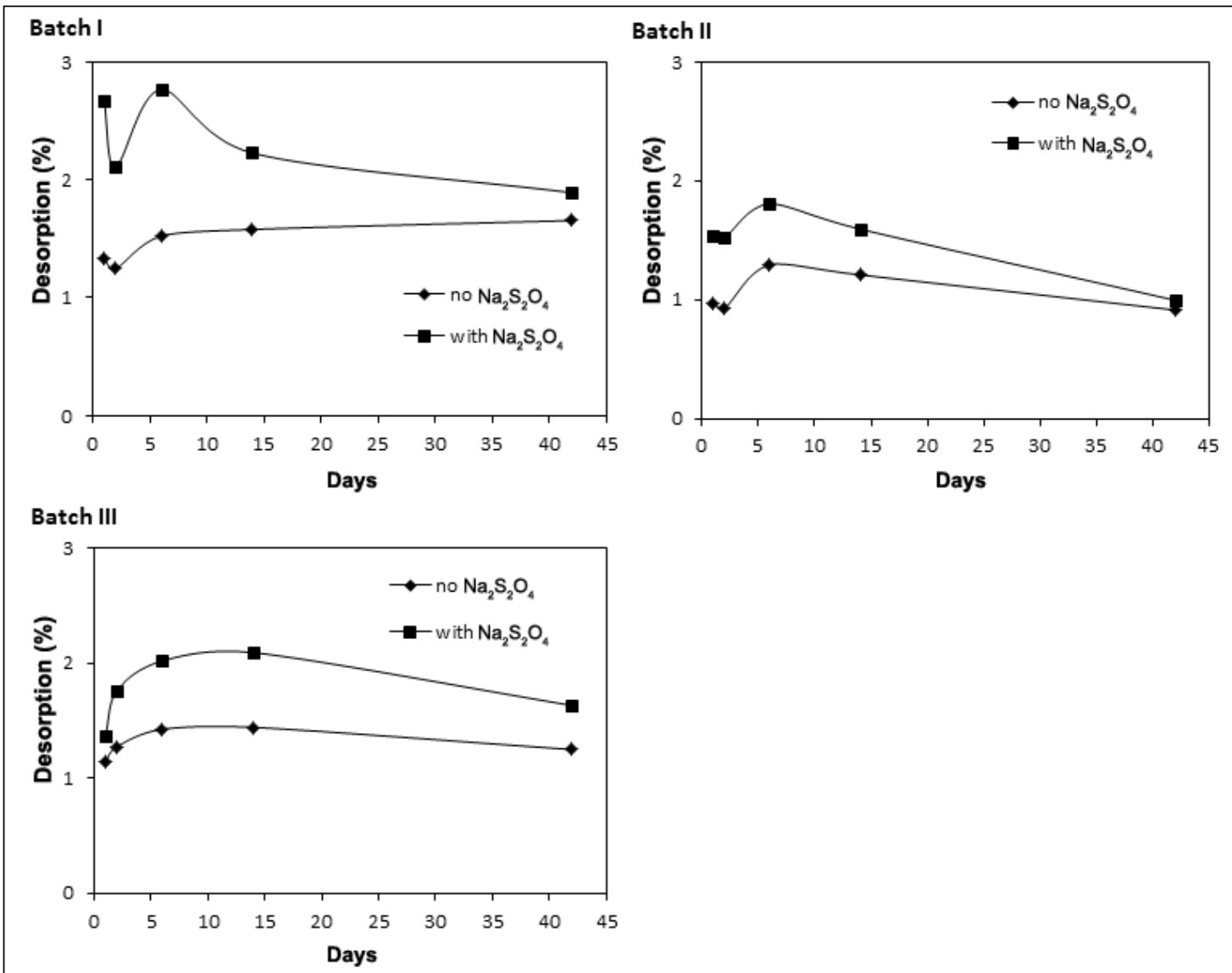

Fig. 5. Kinetics of iodine desorption from HCP with deionized water within 42 days. 
of experiments. The obtained results allow supposing that the alteration of iodine speciation can occur in the lattice of cement and leads to formation of solubilitylimiting phases by reaction with cement components. In addition, immobilization of iodine by cement under alkaline conditions could result from the substitution of $\mathrm{SO}_{4}^{2-}$ by $\mathrm{I}^{-}$[24] or adsorption by oxides and metal hydroxides because of their high zero points of charge (ZPC). Iron and aluminum oxides are distinguished for adsorption of anionic species [25]. Portland cement used in our batch experiments is mainly composed of $\mathrm{CaO}(68.6 \%)$ and $\mathrm{SiO}_{2}(14.6 \%)$ as calcium silicate oxide, $\mathrm{Ca}_{3}\left(\mathrm{SiO}_{4}\right) \mathrm{O}$, and calcium aluminum oxide, $\mathrm{Ca}_{3} \mathrm{Al}_{2} \mathrm{O}_{6}$. After hydration $34.1 \%$ of portlandite, $\mathrm{Ca}(\mathrm{OH})_{2}$, and $23.0 \%$ of calcium silicate oxide, $\mathrm{Ca}_{3}\left(\mathrm{SiO}_{4}\right) \mathrm{O}$, were obtained in hardened cement paste (HCP). In our experiment portlandite is responsible for the alkalinity of HCP suspension. We suppose that incorporation of iodine to cement may occur because of replacing the $\mathrm{OH}^{-}$by $\mathrm{I}^{-}$and formation of a new hydrate [16]. Based on these observations the mechanisms of sorption of iodine by cement under oxidizing highly alkaline conditions remain ambiguous, therefore, further comprehensive structural and chemical analysis is necessary to obtain the knowledge of iodine sorption mechanisms.

\section{Conclusions}

The present experimental work studied the iodine uptake by hardened cement paste under highly alkaline aerobic conditions. The sorption of iodine by cement is governed by its speciation. HPLC analysis of the iodine shows that the iodine speciation remained unchanged in the solution during the experiment. The results of sorption experiments showed that after one day of the experiment $45-56 \%$ of iodine, when in a reduced form as iodide $\left(\mathrm{I}^{-}\right)$, and $79-85 \%$ of iodine in the batch experiments without a reductant were immobilized in HCP. The obtained results allow supposing that the alteration of iodine speciation can occur in the lattice of cement and leads to formation of solubility-limiting phases by reaction with cement components. $K_{\mathrm{d}}$ values obtained in the experiment without a reductant are from 2 to 11 times higher than those in the batch experiment with a reductant. Strong binding of iodine with cementitious materials was demonstrated by the desorption experiment. The amount of iodine obtained in the solutions after leaching did not exceed $1-3 \%$ within 42 days.

\section{Acknowledgements}

We would like to thank the Open Access Center of Electronic Microscopy, X-ray Diffractometry and
Spectroscopy at the Center for Physical Sciences and Technology for the XRD, XRF and SEM analysis.

\section{References}

[1] J. Tits, E. Wieland, C.J. Müller, C. Landesman, and M.H. Bradbury, Strontium binding by calcium silicate hydrates, J. Colloid Interface Sci. 300(1), 78-87 (2006).

[2] M. Harfouche, E. Wieland, R. Dähn, T. Fujita, J. Tits, D. Kunz, and M. Tsukamoto, EXAFS study of $\mathrm{U}(\mathrm{VI})$ uptake by calcium silicate hydrates, J. Colloid Interface Sci. 303(1), 195-204 (2006).

[3] X. Gaona, R. Dähn, J. Tits, A.C. Scheinost, and E. Wieland, Uptake of $\mathrm{Np}(\mathrm{IV})$ by C-S-H phases and cement paste: an EXAFS study, Environ. Sci. Technol. 45(20), 8765-8771 (2011).

[4] F.P. Glasser, J. Marchand, and E. Samson, Durability of concrete-degradation phenomena involving detrimental chemical reactions, Cement Concr. Res. 38(2), 226-246 (2008).

[5] A. Stockdale and N.D. Bryan, The influence of natural organic matter on radionuclide mobility under conditions relevant to cementitious disposal of radioactive wastes: A review of direct evidence, Earth Sci. Rev. 121, 1-17 (2013).

[6] D. Jacques, L. Wang, E. Martens, and D. Mallants, Modelling chemical degradation of concrete during leaching with rain and soil water types, Cement Concr. Res. 40(8), 1306-1313 (2010).

[7] N.D.M. Evans, Binding mechanisms of radionuclides to cement, Cement Concr. Res. 38(4), 543553 (2008).

[8] G. Klevinskas, A. Juodis, R. Plukienè, A. Plukis, and V. Remeikis, Analysis of iodine release from the defective fuel elements of the RBMK-1500 reactor, Lith. J. Phys. 47(2), 211-219 (2007).

[9] G. Klevinskas, A. Juodis, A. Plukis, R. Plukiené, and V. Remeikis, Determination of I-129 activity in the RBMK-1500 main circulation circuit, Nucl. Eng. Des. 238(7), 1518-1524 (2008).

[10] V. Remeikis, A. Plukis, A. Juodis, A. Gudelis, D. Lukauskas, R. Druteikienè, G. Lujanienè, B. Lukšienè, R. Plukienè, and G. Duškesas, Study of the nuclide inventory of operational radioactive waste for the RBMK-1500 reactor, Nucl. Eng. Des. 239(4), 813-818 (2009).

[11]A. Jermolajev, L. Juodis, R. Druteikiene, and V. Remeikis. Implementation of the indirect assessment method for I-129 and Cs-135 accumulation in the RBMK-1500 reactor coolant purification system, Nucl. Eng. Des. 267, 132-139 (2014).

[12] S.D. Park, J.S. Kim, S.H. Han, Y.K. Ha, K.S. Song, and K.Y. Jee, The measurement of $129 \mathrm{I}$ in the cement and the paraffin solidified low and intermediate level wastes (LILWs), spent resin or evaporated bottom from the pressurized water reactor 
(PWR) nuclear power plants, Appl. Radiat. Isot. 67(9), 1676-1682 (2009).

[13]M. Fuhrmann, S. Bajt, and M.A. Schoonen, Sorption of iodine on minerals investigated by $\mathrm{X}$-ray absorption near edge structure (XANES) and ${ }^{125} \mathrm{I}$ tracer sorption experiments, Appl. Geochem. 13(2), 127-137 (1998).

[14]I. Bonhoure, A.M. Scheidegger, E. Wieland, and R. Dahn, Iodine species uptake by cement and $\mathrm{CSH}$ studied by I K-edge X-ray absorption spectroscopy, Radiochim. Acta 90, 647-651 (2002).

[15] M. Toyohara, M. Kaneko, H. Ueda, N. Mitsutsuka, H. Fujihara, T. Murase, and N. Saito, Iodine sorption onto mixed solid alumina cement and calcium compounds, J. Nucl. Sci. Tech. 37(11), 970-978 (2000).

[16] M. Toyohara, M. Kaneko, H. Ueda, N. Mitsutsuka, H. Fujihara, N. Saito, and T. Murase, Contribution to understanding iodine sorption mechanism onto mixed solid alumina cement and calcium compounds, J. Nucl. Sci. Tech. 39(9), 950-956 (2002).

[17]LST EN 196-6:2010 Methods of Testing Cement Part 6: Determination of Fineness (Lithuanian Standards Board, 2010).

[18]J. Tits, A. Jakob, E. Wieland, and P. Spieler, Diffusion of tritiated water and $22 \mathrm{Na}^{+}$through non-degraded hardened cement pastes, J. Contam. Hydrol. 61(1-4), 45-62 (2003).
[19] S. Yang, J. Li, Y. Lu, Y. Chen, and X. Wang, Sorption of $\mathrm{Ni}(\mathrm{II})$ on GMZ bentonite: Effects of $\mathrm{pH}$, ionic strength, foreign ions, humic acid and temperature, Appl. Radiat. Isot. 67(9), 1600-1608 (2009).

[20] M. Honty, M. De Craen, L. Wang, J. Madejova, A. Czimerova, M. Pentrak, I. Striček, and M. Van Geet, The effect of high $\mathrm{pH}$ alkaline solutions on the mineral stability of the Boom Clay - Batch experiments at $60^{\circ} \mathrm{C}$, Appl. Geochem. 25(6), 825-840 (2010).

[21] I. Neretnieks, Development of a simple model for the simultaneous degradation of concrete and clay in contact, Appl. Geochem. 43, 101-113 (2014).

[22]D. Kaplan and G. Iverson, I-129 Test and Research to Support Disposal Decisions (2001), http://www. osti.gov/bridge/

[23] M.I. Ojovan, G.A. Varlackova, Z.I. Golubeva, and O.N. Burlaka, Long-term field and laboratory leaching tests of cemented radioactive wastes, J. Hazard. Mater. 187(1-3), 296-302 (2011).

[24] M. Atkins and F.P. Glasser, Application of portland cement-based materials to radioactive waste immobilization, Waste Manag. 12(2-3), 105-115 (1992).

[25]D.A. Sverjensky and K. Fukushi, Anion adsorption on oxide surface: inclusion of the water dipole in modeling the electrostatics of ligand exchange, Environ. Sci. Technol. 40(1), 263-271 (2006).

\title{
RADIOAKTYVIŲJŲ ATLIEKŲ KIETINIMAS CEMENTU: JODO JUNGTIS SU BETONU STIPRIAI ŠARMINĖJE APLINKOJE
}

\author{
R. Druteikienè, J. Šapolaitė, Ž. Ežerinskis, E. Naujalis, A. Puzas \\ Valstybinis moksliniu tyrimy institutas Fiziniu ir technologijos mokslu centras, Vilnius, Lietuva
}

\section{Santrauka}

Radioaktyviųjų atliekų saugyklų inžinerinių barjerų funkcija - užtikrinti ilgalaikị ir saugu pavojingu atliekų laikymą užkertant kelią nekontroliuojamam radionuklidų sklidimui ì aplinką. Potencialus radionuklidų sklidimas per saugyklų inžinerinius barjerus gali atsirasti dèl oksiduojančio / redukuojančio aplinkos poveikio ir dèl to susidarančių radioaktyviųjų elementų cheminių savybių pokyčių. Radioaktyviųjų elementų sulaikymas kietinančioje matricoje yra svarbi sąlyga, leidžianti užtikrinti efektyvų radioaktyviųjų atliekų saugojimą.
Darbe buvo tiriama jodo $\left({ }^{127} \mathrm{I}\right)$ sorbcijos i hidratuotą cementą ir išplovimo iš jo kinetika, proceso priklausomybè nuo elemento cheminès formos stipriai šarminejje $(\mathrm{pH}>12)$ terpeje naudojant / nenaudojant reduktoriu $\mathrm{Na}_{2} \mathrm{~S}_{2} \mathrm{O}_{4}$. Nustatytas jodo pasiskirstymo tarp kietos ir skystos fazés koeficientas $\left(K_{\mathrm{d}}\right)$. Eksperimentineje sistemoje be reduktoriaus jodo $K_{\mathrm{d}}$ kito $172-1095 \mathrm{~mL} \mathrm{~g}^{-1}$ ribose, sistemoje su reduktoriumi jodido $\left(\mathrm{I}^{-}\right) K_{\mathrm{d}}$ siekè $83-92 \mathrm{~mL} \mathrm{~g}^{-1}$.

Eksperimento rezultatai rodo, kad stipriai šarminejje aplinkoje jodas yra efektyviai fiksuojamas cemento matricoje ir jo sorbcija priklauso nuo jodo oksidacijos laipsnio. 